\title{
PENGARUH KAPASITAS SUMBERDAYA MANUSIA DAN \\ PEMANFAATAN TEKNOLOGI INFORMASI TERHADAP KUALITAS \\ LAPORAN KEUANGAN PEMERINTAH DAERAH DENGAN VARIABEL \\ INTERVENING SISTEM PENGENDALIAN INTERN PEMERINTAH \\ Studi pada Satuan Kerja Perangkat Daerah Kota Cirebon
}

\author{
Deasy Hary Rahman Puspita \\ Dewi Amalia
}

\begin{abstract}
The quality of local government financial reporting is influenced by several factors: human resources capacity, information technology utilization, and system of government internal control. Independent variable in this research are human resources capacity, information technology utilization, and system of government internal control as intervening variable, and quality of local government financial reporting as dependent variable. Respondents on this research are SKPD's accounting departement in Cirebon. This research use purposive sampling with 84 respondents. The result found that human resources capacity have influence toward quality of local government financial reporting, while information technology utilization, and system of government internal control have not influence toward quality of local government financial reporting. The human resources capacity and information technology utilization have influence toward system of government internal control. The main requirement testing intervening variable is a variable system of government internal control have influence toward quality of local government financial reporting. The results showed tha system of government internal control have no influence toward quality of local government financial reporting.
\end{abstract}

Keywords: The quality of local government financial reporting, human resources capacity, information tecnology utilization, system of government internal control, and path analysis.

\section{PENDAHULUAN}

Perkembangan sektor publik di Indonesia ditandai dengan menguatnya tuntutan akuntabilitas atas lembaga-lembaga publik, baik di pusat maupun daerah. Akuntabilitas publik dalam konteks organisasi pemerintah adalah pemberian informasi dan pengungkapan atas aktivitas dan kinerja finansial pemerintah kepada pihak-pihak yang berkepentingan dengan laporan tersebut. Akuntabilitas publik 
dapat diartikan sebagai bentuk kewajiban pihak pemegang amanah (agent) untuk memberikan pertanggungjawaban, menyajikan, melaporkan, dan mengungkapkan segala aktivitas dan kegiatan yang menjadi tanggungjawabnya kepada pihak pemberi amanah (principal) yang memiliki hak dan kewenangan untuk meminta pertanggungjawaban tersebut (Mardiasmo, 2009: 20).

Menurut Musa (2013) kualitas pelaporan keuangan negara/daerah sudah banyak mengalami perbaikan. Misalnya pada tahun 2008 hanya terdapat 13 dari 485 laporan keuangan pemerintah daerah yang memperoleh opini wajar tanpa pengecualian (WTP), dan kemudian meningkat menjadi 113 laporan keuangan dari 415 laporan keuangan pemerintah daerah yang diperiksa pada tahun 2012.

Kapasitas sumberdaya manusia adalah kemampuan sumberdaya manusia untuk melaksanakan tugas dan tanggung jawab yang diberikan kepadanya dengan bekal pendidikan, pelatihan, dan pengalaman yang cukup memadai. Tuasikal (2007) dalam penelitian Arfianti (2011) menyatakan bahwa untuk menghasilkan informasi keuangan yang bermanfaat bagi para pemakai, maka laporan keuangan harus disusun oleh personil yang memiliki kompetensi di bidang pengelolaan keuangan daerah dan sistem akuntansi.

Hal penting lainnya yang tidak boleh diabaikan jika berbicara tentang kualitas laporan keuangan pemerintah daerah adalah sistem pengendalian intern pemerintah. SPIP merupakan suatu cara untuk mengarahkan, mengawasi, dan mengukur sumberdaya suatu organisasi serta memiliki peran penting dalam pencegahan dan pendeteksian penggelapan ( $f r a u d)$ secara dini.

Peneliti memilih Kota Cirebon sebagai tempat penelitian. Alasan peneliti mengambil tempat penelitian di Kota Cirebon adalah Peraturan Pemerintah Nomor 71 Tahun 2010 tentang Standar Akuntansi Pemerintahan (SAP) baru diterapkan pada tahun 2012. Selain itu, hasil audit laporan keuangan pemerintah daerah Kota Cirebon tahun 2012 oleh BPK memperoleh opini wajar dengan pengecualian (WDP). Hal itu menunjukkan bahwa laporan keuangan pemerintah daerah Kota Cirebon belum sepenuhnya mengaplikasikan Peraturan Pemerintah Nomor 71 Tahun 2010 tentang Standar Akuntansi Pemerintahan (SAP). Penelitian ini memfokuskan pada Satuan Kerja Perangkat Daerah (SKPD), alasannya karena 
laporan keuangan pemerintah daerah merupakan laporan keuangan konsolidasi dari laporan keuangan SKPD sehingga kualitas laporan keuangan pemerintah daerah tergantung pada kualitas laporan keuangan SKPD di dalamnya. Berdasar latar belakang masalah, maka peneliti tertarik untuk melakukan penelitian mengenai pengaruh kapasitas sumberdaya manusia dan pemanfaatan teknologi informasi terhadap kualitas laporan keuangan pemerintah daerah dengan variabel intervening sistem pengendalian intern pemerintah.

\section{TINJAUAN PUSTAKA DAN PENGEMBANGAN HIPOTESIS}

\section{Kapasitas Sumberdaya Manusia}

Sumberdaya merupakan sumber energi, tenaga, kekuatan yang diperlukan untuk menciptakan daya, gerakan, aktivitas, kegiatan, dan tindakan. Sumberdaya tersebut terdiri atas sumberdaya alam, sumberdaya finansial, sumberdaya manusia, sumberdaya teknologi, dan sumberdaya pengetahuan. Menurut Peraturan Presiden Republik Indonesia Nomor 59 Tahun 2012 tentang Kerangka Nasional Pengembangan Kapasitas Pemerintahan Daerah, pengembangan kapasitas sumberdaya manusia dilakukan dalam upaya meningkatkan kapasitas pemerintah daerah meliputi peningkatan pengetahuan dan wawasan, keterampilan dan keahlian, serta pembentukan sikap dan perilaku kerja penyelenggara pemerintahan daerah. Semakin baik kapasitas sumberdaya manusia maka laporan keuangan pemerintah daerah yang dihasilkan akan semakin baik.

\section{Pemanfaatan Teknologi Informasi}

Penggunaan teknologi informasi mempunyai andil yang besar untuk mencapai laporan keuangan yang berkualitas. Teknologi informasi berfungsi sebagai pemrosesan, penyimpanan informasi, dan penyebaran informasi. Peraturan Pemerintah Republik Indonesia Nomor 65 Tahun 2010 tentang Sistem Informasi Keuangan Daerah, menjelaskan bahwa untuk menindaklanjuti terselenggaranya proses pembangunan yang sejalan dengan prinsip tata pemerintahan yang baik (good governance), pemerintah pusat dan pemerintah daerah berkewajiban untuk mengembangkan dan memanfaatkan kemajuan teknologi informasi untuk 
meningkatkan kemampuan mengelola keuangan daerah, dan menyalurkan informasi keuangan daerah kepada pelayanan public

\section{Sistem Pengendalian Intern Pemerintah}

Menurut Peraturan Pemerintah Nomor 60 Tahun 2008 tentang Sistem Pengendalian Intern Pemerintah (SPIP), SPIP merupakan suatu cara untuk mengarahkan, mengawasi, dan mengukur sumberdaya organisasi, dan juga memiliki peran penting dalam pencegahan dan pendeteksian penggelapan (fraud) secara dini. Unsur sistem pengendalian intern pemerintah: (a) lingkungan pengendalian, (b) penilaian risiko, (c) aktivitas pengendalian, (d) informasi dan komunikasi, serta (e) pemantauan.

\section{Kualitas Laporan Keuangan}

Menurut Peraturan Pemerintah Nomor 71 Tahun 2010, karakteristik kualitatif laporan keuangan adalah ukuran-ukuran normatif yang perlu diwujudkan dalam informasi akuntansi sehingga dapat memenuhi tujuannya. Keempat karakteristik berikut ini merupakan prasyarat normatif yang diperlukan agar laporan keuangan pemerintah dapat memenuhi kualitas yang dikehendaki yaitu:

a. Relevan, informasi yang relevan yaitu memiliki manfaat, umpan balik, memiliki manfaat prediktif, tepat waktu, dan lengkap.

b. Adil, informasi dalam laporan keuangan bebas dari pengertian yang menyesatkan dan kesalahan material, menyajikan setiap fakta secara jujur, serta dapat diverifikasi.

c. Dapat dibandingkan, informasi yang termuat dalam laporan keuangan akan lebih berguna jika dapat dibandingkan dengan laporan keuangan perioda sebelumnya atau laporan keuangan entitas pelaporan lain pada umumnya.

d. Dapat dipahami, informasi yang disajikan dalam laporan keuangan dapat dipahami oleh pengguna dan dinyatakan dalam bentuk serta istilah yang disesuaikan dengan batas pemahaman para pengguna. 


\section{Pengaruh Kapasitas Sumberdaya Manusia terhadap Kualitas Laporan Keuangan Pemerintah Daerah Kota Cirebon}

Sumberdaya manusia yang ada di lingkungan pemerintah daerah Kota Cirebon dituntut untuk memiliki tingkat akuntansi yang memadai atau paling tidak memiliki kemauan untuk terus belajar dan mengasah kemampuan di bidang akuntansi. Oleh karena itu, kapasitas sumberdaya manusia sangat berperan dalam menghasilkan laporan keuangan yang berkualitas. Hasil penelitian Delanno (2012) dan Yosefrinaldi (2013) membuktikan bahwa kapasitas sumberdaya manusia berpengaruh terhadap kualitas laporan keuangan. Berdasarkan uraian tersebut, maka hipotesis yang diajukan adalah sebagai berikut:

H1: Kapasitas sumberdaya manusia berpengaruh terhadap kualitas laporan keuangan pemerintah daerah Kota Cirebon.

\section{Pengaruh Pemanfaatan Teknologi Informasi terhadap Kualitas Laporan Keuangan Pemerintah Daerah Kota Cirebon}

Pemerintah pusat dan pemerintah daerah berkewajiban untuk mengembangkan dan memanfaatkan kemajuan teknologi informasi untuk meningkatkan kemampuan mengelola keuangan daerah, serta menyalurkan informasi keuangan daerah kepada pelayanan publik. Pengolahan data dengan memanfaatkan teknologi informasi (komputer dan jaringan) akan memberikan banyak keunggulan baik dari sisi keakuratan/ketepatan hasil. Pemanfaatan teknologi informasi juga akan mengurangi kesalahan yang terjadi. Semakin besar pemanfaatan teknologi informasi maka kualitas laporan keuangan yang dihasilkan pemerintah akan semakin baik pula. Penelitian sebelumnya oleh Indriasari (2008) menunjukkan bahwa pemanfaatan teknologi informasi berpengaruh terhadap nilai informasi laporan keuangan pemerintah. Berdasarkan uraian tersebut, maka hipotesis yang diajukan adalah sebagai berikut:

H2: Pemanfaatan teknologi informasi berpengaruh terhadap kualitas laporan keuangan pemerintah daerah Kota Cirebon. 


\section{Pengaruh Kapasitas Sumberdaya Manusia terhadap Sistem Pengendalian Intern Pemerintah Daerah Kota Cirebon}

Hubungan kapasitas sumberdaya manusia terhadap sistem pengendalian intern pemerintah (SPIP) berhubungan dengan unsur SPIP yaitu kegiatan pengendalian. Kegiatan pengendalian membantu memastikan bahwa arahan pimpinan instansi pemerintah dilaksanakan oleh para pegawai secara efektif dan efisien dalam pencapaian tujuan organisasi. Aspek yang paling penting dari pengendalian internal adalah personil. Jika karyawan adalah orang yang kompeten dan bisa dipercaya, pengendalian lain bisa tidak ada dan laporan keuangan yang bisa diandalkan masih bisa dihasilkan. Penelitian Delanno (2012) membuktikan bahwa kapasitas sumberdaya manusia berpengaruh terhadap sistem pengendalian intern pemerintah. Berdasarkan uraian tersebut, maka hipotesis yang diajukan adalah sebagai berikut:

H3: Kapasitas sumberdaya manusia berpengaruh terhadap sistem pengendalian intern pemerintah daerah Kota Cirebon.

\section{Pengaruh Pemanfaatan Teknologi Informasi terhadap Sistem Pengendalian Intern Pemerintah Daerah Kota Cirebon}

Pemanfaatan teknologi informasi berkaitan dengan unsur informasi dan komunikasi. Pimpinan instansi pemerintah wajib mengidentifikasi, mencatat, dan mengkomunikasikan informasi dalam bentuk dan waktu yang tepat. Komunikasi atas informasi wajib diselenggarakan secara efektif. Pimpinan instansi pemerintah harus menyediakan dan memanfaatkan berbagai bentuk dan sarana komunikasi, serta mengelola, mengembangkan, dan memperbarui sistem informasi secara terus menerus. Penelitian Puspitasari (2013) menunjukkan hasil bahwa teknologi informasi berpengaruh terhadap sistem akuntansi. Berdasarkan uraian tersebut, maka hipotesis yang diajukan adalah sebagai berikut:

H4: Pemanfaatan teknologi informasi berpengaruh terhadap sistem pengendalian intern pemerintah daerah Kota Cirebon. 


\section{Pengaruh Sistem Pengendalian Intern Pemerintah terhadap Kualitas Laporan Keuangan Pemerintah Daerah Kota Cirebon}

Peraturan Pemerintah Nomor 60 Tahun 2008 mendefinisikan, sistem pengendalian intern adalah proses yang integral pada tindakan dan kegiatan yang dilakukan secara terus menerus oleh pimpinan dan seluruh pegawai untuk memberikan keyakinan yang memadai atas tercapainya tujuan organisasi melalui kegiatan yang efektif dan efisien, keandalan pelaporan keuangan, pengamanan aset negara, dan ketaatan terhadap peraturan perundang-undangan. Semakin baik sistem pengendalian intern pemerintah maka laporan keuangan yang dihasilkan semakin berkualitas. Penelitian Yosefrinaldi (2013) membuktikan bahwa sistem pengendalian intern pemerintah memiliki pengaruh terhadap kualitas laporan keuangan. Berdasarkan uraian tersebut, maka hipotesis yang diajukan adalah sebagai berikut:

H5: Sistem pengendalian intern pemerintah berpengaruh terhadap kualitas laporan keuangan pemerintah daerah Kota Cirebon.

\section{Pengaruh Kapasitas Sumberdaya Manusia terhadap Kualitas Laporan Keuangan Pemerintah Daerah dengan Mediasi Sistem Pengendalian Intern Pemerintah}

Kemampuan sumberdaya manusia dalam menghasilkan laporan keuangan yang memiliki nilai informasi dapat dirancang melalui suatu sistem pengendalian internal dengan tujuan umumnya adalah efisiensi dan efektivitas operasi. Pengendalian dalam organisasi akan mendorong pemakaian sumberdaya, mencakup personil, secara efisien dan efektif untuk mengoptimalkan sasaran-sasaran organisasi. Aspek yang paling penting dari pengendalian internal adalah personil. Jika karyawan adalah orang yang kompeten dan bisa dipercaya, pengendalian lain bisa tidak ada dan laporan keuangan yang bisa diandalkan masih bisa dihasilkan. Hasil penelitian Delanno (2012) menunjukkan bahwa sistem pengendalian intern pemerintah mampu memediasi kapasitas sumberdaya manusia terhadap kualitas laporan keuangan pemerintah daerah. Berdasarkan uraian tersebut, maka hipotesis yang diajukan adalah sebagai berikut: 
H6: Sistem pengendalian intern pemerintah dapat memediasi pengaruh kapasitas sumberdaya manusia terhadap kualitas laporan keuangan pemerintah daerah Kota Cirebon.

\section{Pengaruh Pemanfaatan Teknologi Informasi terhadap Kualitas Laporan} Keuangan Pemerintah Daerah dengan Mediasi Sistem Pengendalian Intern

\section{Pemerintah.}

Pemanfaatan teknologi informasi oleh entitas dapat meningkatkan efektivitas dan efisiensi dari pengendalian internal dengan secara konsisten memroses sejumlah besar volume transaksi data sehingga teknologi informasi dapat meningkatkan ketepatan waktu dan akurasi dari informasi. Satu keuntungan teknologi informasi adalah kemampuan untuk meningkatkan pengendalian internal dengan menggabungkan kendali yang dilakukan komputer dalam aktivitas proses transaksi sehari-hari. Berdasarkan uraian tersebut, maka hipotesis yang diajukan adalah sebagai berikut:

H7: Sistem pengendalian intern pemerintah dapat memediasi pengaruh pemanfaatan teknologi informasi terhadap kualitas laporan keuangan pemerintah daerah Kota Cirebon.

\section{Model Penelitian}

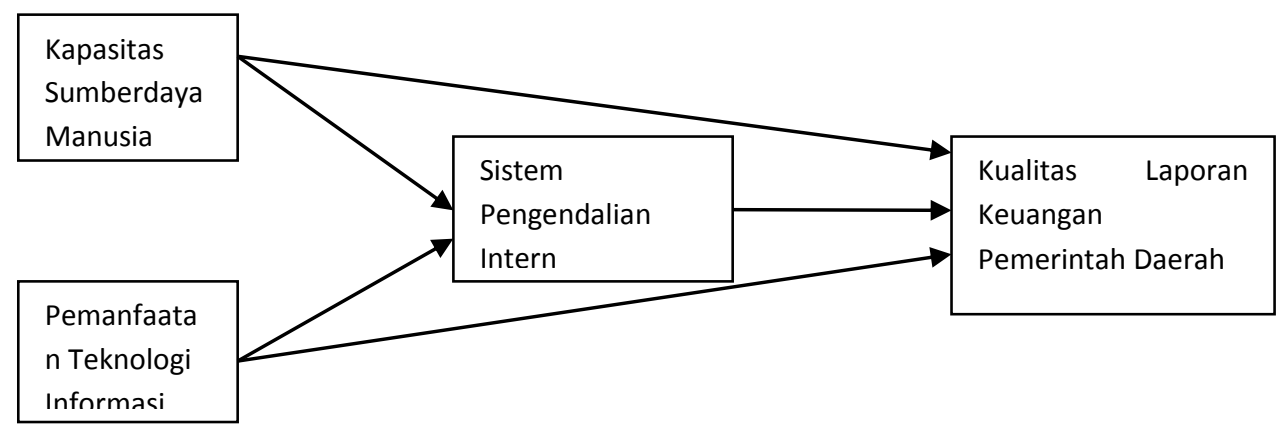

Gambar 1

Model Penelitian 


\section{METODA PENELITIAN}

\section{Populasi dan Sampel}

Populasi dalam penelitian ini adalah karyawan bagian akuntansi/penatausahaan keuangan pada Satuan Kerja Perangkat Daerah (SKPD) di Kota Cirebon. Pengambilan sampel atas responden dilakukan secara purposive sampling. Kriteria responden dalam penelitian ini adalah:

a. Para pegawai yang melaksanakan fungsi akuntansi/tata usaha keuangan pada SKPD di Kota Cirebon.

b. Responden ditetapkan pada kepala subbagian, staf pencatatan keuangan/akuntansi, dan staf pemegang kas SKPD di Kota Cirebon.

Penentuan responden tersebut didasarkan pada asumsi bahwa kepala subbagian, bagian pencatatan akuntansi, dan pemegang kas merupakan pihak yang terlibat langsung secara teknis dalam pencatatan transaksi keuangan SKPD dan penyusunan pelaporan keuangan pada tiap SKPD.

\section{Definisi Operasional dan Pengukuran Variabel}

\section{Kualitas Laporan Keuangan}

Menurut Peraturan Pemerintah Nomor 71 Tahun 2010 tentang Standar Akuntansi Pemerintahan, karakteristik kualitatif laporan keuangan adalah ukuranukuran normatif yang perlu diwujudkan dalam informasi akuntansi sehingga dapat memenuhi tujuannya. Ukuran-ukuran kualitas laporan keuangan tersebut adalah relevan, andal, dapat dipahami, dan dapat dibandingkan. Pengukuran variabel ini menggunakan instrumen kuesioner yang digunakan dalam penelitian Yosefrinaldi (2013) yang diukur dengan 5 skala Likert.

\section{Kapasitas Sumber Daya Manusia}

Menurut Peraturan Presiden Republik Indonesia Nomor 59 Tahun 2012 tentang Kerangka Nasional Pengembangan Kapasitas Pemerintahan Daerah, pengembangan kapasitas sumberdaya manusia meliputi peningkatan pengetahuan dan wawasan, keterampilan dan keahlian, serta pembentukan sikap dan perilaku kerja penyelenggara pemerintahan daerah. Pengukuran variabel ini menggunakan 
instrumen kuesioner yang digunakan dalam penelitian Yosefrinaldi (2013), diukur dengan 5 skala likert.

\section{Pemanfaatan Teknologi Informasi}

Menurut Peraturan Pemerintah Nomor 65 Tahun 2010 tentang Sistem Informasi Keuangan Daerah, pemerintah pusat dan pemerintah daerah berkewajiban untuk mengembangkan dan memanfaatkan kemajuan teknologi informasi untuk meningkatkan kemampuan mengelola keuangan daerah, serta menyalurkan informasi keuangan daerah kepada pelayanan publik. Pengukuran variabel ini menggunakan instrumen kuesioner yang digunakan dalam penelitian Yosefrinaldi (2013) yang diukur dengan 5 skala likert.

\section{Sistem Pengendalian Intern Pemerintah}

Menurut Peraturan Pemerintah Nomor 60 Tahun 2008 tentang Sistem Pengendalian Intern Pemerintah, sistem pengendalian intern adalah proses yang integral pada tindakan dan kegiatan yang dilakukan secara terus-menerus oleh pimpinan dan seluruh pegawai untuk memberikan keyakinan yang memadai atas tercapainya tujuan organisasi melalui kegiatan yang efektif dan efisien, keandalan pelaporan keuangan, pengamanan aset negara, dan ketaatan terhadap peraturan perundang-undangan. Pengukuran variabel ini menggunakan instrumen kuesioner yang digunakan dalam penelitian Yosefrinaldi (2013) yang diukur dengan 5 skala likert.

\section{Teknik Analisis Data}

\section{Uji Kualitas Data}

Uji validitas digunakan untuk mengukur sah atau valid tidaknya suatu kuesioner. Instrumen valid jika mampu mengukur apa yang seharusnya diukur dengan korelasi product moment dari Pearson.

Suatu kuesioner dikatakan reliabel atau handal jika jawaban seseorang terhadap pernyataan adalah konsisten atau stabil dari waktu ke waktu (Ghozali, 2011: 47). Uji reliabilitas ini menggunakan teknik Cronbach Alpha. 


\section{Analisis Jalur (Path Analysis)}

Path analysis merupakan analisis yang digunakan untuk mengetahui efek langsung dan tidak langsung variabel independen dengan variabel dependen, dengan syarat variabel yang lain konstan. Path analysis berfungsi untuk menentukan pola hubungan antara tiga atau lebih variabel dan tidak dapat digunakan untuk mengkonfirmasi atau menolak hipotesis kasualitas imajiner (Ghozali, 2011: 249). Pengujian model 1 dalam penelitian ini dapat dijelaskan dengan struktur jalur pada gambar 2 sebagai berikut:

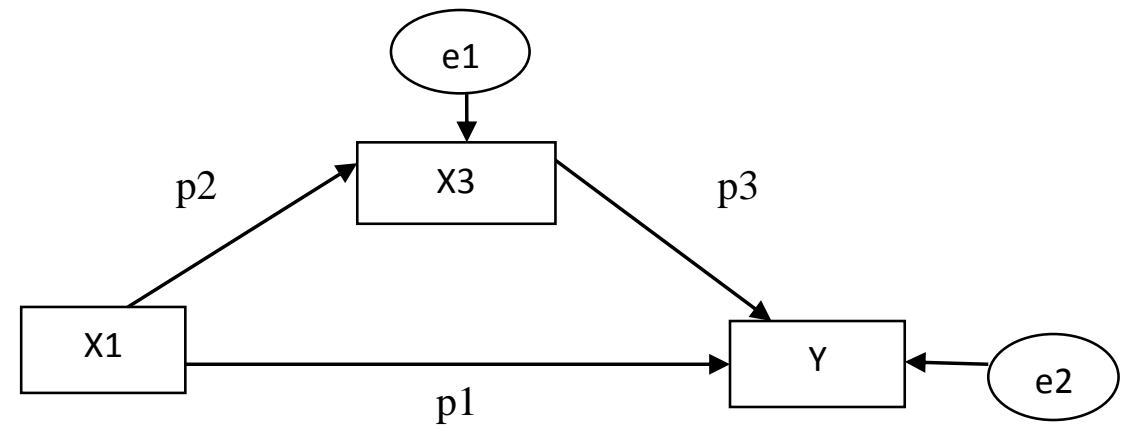

Sumber: Ghozali (2011)

Gambar 2

Diagram Path Analysis

Total pengaruh hubungan dari kapasitas sumberdaya manusia terhadap kualitas laporan keuangan disebut pengaruh langsung yang ditunjukkan dengan nilai $\mathrm{p} 1$, ditambah dengan pengaruh tidak langsung yang merupakan perkalian dari p2 dengan p3. Pengujian model 2 dalam penelitian ini dapat dijelaskan dengan struktur jalur pada gambar 3 sebagai berikut:

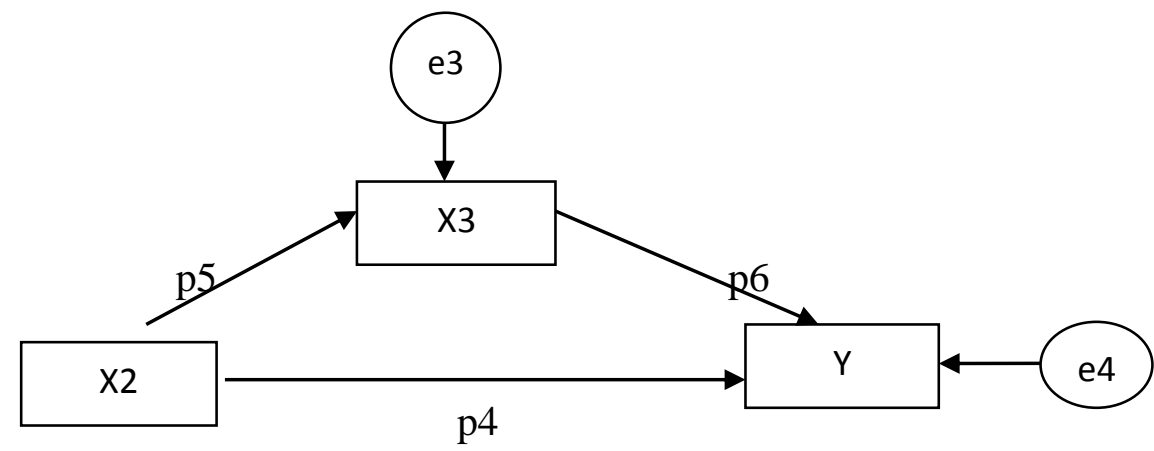

Sumber: Ghozali (2011)

Gambar 3

Diagram Path Analysis 
Total pengaruh hubungan dari pemanfaatan teknologi informasi terhadap kualitas laporan keuangan disebut pengaruh langsung yang ditunjukkan dengan nilai $\mathrm{p} 4$, ditambah dengan pengaruh tidak langsung yang merupakan perkalian dari p5 dengan p6. Jika nilai t hitung lebih besar dari t tabel dengan tingkat signifikansi 0,05 , maka dapat disimpulkan ada pengaruh mediasi.

\section{Uji Asumsi Klasik}

\section{Uji Normalitas}

Uji normalitas bertujuan untuk menguji model regresi, nilai variabel penggangu atau residual memiliki distribusi normal (Ghozali, 2011: 160). Pada penelitian ini digunakan pengujian Kolmogorov-Smirnov goodness of fit test terhadap model yang diuji.

\section{Uji Multikolinieritas}

Multikolinearitas merupakan suatu keadaan tidak terdapat atau terjadi korelasi liniar di antara dua atau lebih variabel independen. Menurut Ghozali (2011: 106), untuk mengetahui ada tidaknya gejala multikolinieritas pada model regresi linear berganda yang diajukan, dapat dilihat pada nilai variance inflation factor (VIF).

\section{Uji Heteroskedastisitas}

Pengujian ini dilakukan untuk melihat variabel pengganggu mempunyai varian yang sama atau tidak. Salah satu metoda yang digunakan untuk menguji ada tidaknya heteroskedastisitas yaitu dengan menggunakan uji Glejser, yaitu dengan meregresikan antara nilai mutlak residual dengan seluruh variabel independen yang ada.

\section{Uji Hipotesis}

\section{Koefisien Determinasi}

Koefisien determinasi $\left(\mathrm{R}^{2}\right)$ pada intinya mengukur kemampuan model dalam menerangkan variasi variabel terikat. Banyak peneliti menganjurkan untuk menggunakan nilai adjusted $R^{2}$ saat mengevaluasi mana model regresi terbaik. 
Tidak seperti $\mathrm{R}^{2}$, nilai adjusted $R^{2}$ dapat naik atau turun apabila satu variabel independen ditambahkan pada model (Ghozali, 2011: 97).

\section{Uji F}

Uji F pada dasarnya menunjukkan semua variabel bebas dalam model berpengaruh atau tidak terhadap variabel terikat. Selain itu, uji F dapat digunakan untuk melihat model regresi yang digunakan sudah signifikan atau belum. dengan ketentuan bahwa jika p value $<(\alpha)=0,05$.

\section{Uji t}

Uji t bertujuan untuk menguji pengaruh secara parsial antara variabel bebas terhadap variabel tidak bebas dengan variabel lain dianggap konstan, dengan asumsi bahwa jika nilai signifikansi yang dapat dilihat dari analisis regresi menunjukkan nilai lebih kecil dari $\alpha=5 \%$.

HASIL DAN PEMBAHASAN

Tabel 1

Rincian Penyebaran dan Pengembalian Kuesioner

\begin{tabular}{|l|c|}
\hline \multicolumn{1}{|c|}{ Keterangan } & Jumlah \\
\hline Kuesioner yang disebar & 91 \\
\hline Kuesioner yang kembali & 84 \\
\hline Kuesioner yang dapat digunakan & 68 \\
\hline Kuesioner yang tidak kembali (91-84) & 7 \\
\hline Tingkat pengembalian kuesioner (84/91 x 100\%) & $92 \%$ \\
\hline Tingkat pengembalian yang digunakan (68/91 x 100\%) & $74 \%$ \\
\hline
\end{tabular}

Sumber: Data primer, diolah (2014)

Jumlah populasi pada penelitian ini adalah 35 Satuan Kerja Perangkat Daerah (SKPD) Kota Cirebon. Setiap sampel masing-masing terdiri dari 3 responden. Dari 35 populasi SKPD hanya 26 SKPD yang dapat diteliti dan 91 kuesioner yang disebar. Hingga batas pengumpulan data, kuesioner yang diterima kembali sebanyak 84 kuesioner dan yang dapat diolah sebanyak 68 kuesioner. 


\section{Uji Kualitas Data}

Hasil uji validitas menunjukkan bahwa variabel kualitas laporan keuangan, kapasitas sumberdaya manusia, pemanfaatan teknologi informasi, dan sistem pengendalian intern pemerintah memiliki nilai signifikansi $<0,05$. Dengan demikian, pernyataan-pernyataan yang ada didalam kuesioner variabel tersebut dinyatakan valid.

Hasil uji reliabilitas terhadap masing-masing pernyataan pengukur variabel penelitian menunjukkan bahwa masing-masing pernyataan memiliki nilai Cronbach Alpha $>0,70$. Berdasar hasil tersebut diketahui bahwa kuesioner yang digunakan dalam penelitian ini reliabel.

\section{ANALISIS PATH}

Uji Asumsi Klasik

a. Uji Normalitas

Tabel 2

Hasil Uji Normalitas

\begin{tabular}{|c|c|c|}
\hline Asymp. Sig. (2-tailed) & Alpha & Keterangan \\
\hline 0,605 & 0,05 & Normal \\
\hline
\end{tabular}

Sumber: Data primer, diolah (2014)

Hasil uji normalitas pada tabel 2 menunjukkan bahwa besarnya nilai asymp. Sig. (2-tailed) adalah 0,605 yang lebih besar dari 0,05. Hasil tersebut menyatakan bahwa data residual terdistribusi secara normal.

\section{b. Uji Multikolinearitas}

\section{Tabel 3}

\section{Hasil Uji Multikolinearitas}

\begin{tabular}{|l|c|c|}
\hline \multicolumn{1}{|c|}{ Variabel } & VIF & \multicolumn{1}{c|}{ Keterangan } \\
\hline Kapasitas Sumberdaya Manusia & 2,762 & Tidak terdapat multikolinearitas \\
\hline Pemanfaatan Teknologi Informasi & 2,828 & Tidak terdapat multikolinearitas \\
\hline $\begin{array}{l}\text { Sistem Pengendalian Intern } \\
\text { Pemerintah }\end{array}$ & 2,797 & Tidak terdapat multikolinearitas \\
\hline
\end{tabular}

Sumber: Data primer, diolah (2014) 
Hasil perhitungan nilai variance inflation factor (VIF) menunjukan semua variabel bebas memiliki nilai VIF $<10$. Berdasar hasil tersebut diketahui bahwa tidak ada multikolinearitas antar variabel independen dalam model regresi.

\section{c. Uji Heteroskedastisitas}

Hasil perhitungan menunjukkan bahwa nilai signifikansi ketiga variabel tersebut lebih besar dari nilai alpha 0,05. Berdasar hasil tersebut diketahui bahwa model regresi tidak terdapat heteroskedastisitas.

Tabel 4

Hasil Uji Heteroskedastisitas

\begin{tabular}{|l|c|c|c|}
\hline \multicolumn{1}{|c|}{ Variabel } & Sig & Alpha & Keterangan \\
\hline Kapasitas Sumberdaya Manusia & 0,576 & 0,05 & Tidak terdapat heteroskedastisitas \\
\hline $\begin{array}{l}\text { Pemanfaatan Teknologi } \\
\text { Informasi }\end{array}$ & 0,579 & 0,05 & Tidak terdapat heteroskedastisitas \\
\hline $\begin{array}{l}\text { Sistem Pengendalian Intern } \\
\text { Pemerintah }\end{array}$ & 0,732 & 0,05 & Tidak terdapat heteroskedastisitas \\
\hline
\end{tabular}

Sumber: Data primer, diolah (2014)

\section{Uji Hipotesis}

\section{a. Koefisien Determinasi}

Tabel 5

Hasil Uji Koefisien Determinasi

\begin{tabular}{|c|l|c|}
\hline No & \multicolumn{1}{|c|}{ Persamaan Regresi } & Adjusted $\boldsymbol{R}^{\mathbf{2}}$ \\
\hline \multirow{2}{*}{1} & $\mathrm{X} 3=\alpha+\mathrm{p} 2 . \mathrm{X} 1+\mathrm{e} 1$ & \multirow{2}{*}{0,550} \\
\cline { 2 - 2 } & $\mathrm{SPIP}=9,295+1,094 \mathrm{SDM}+\mathrm{e} 1$ & \multirow{2}{*}{0,283} \\
\hline \multirow{2}{*}{2} & $\mathrm{Y}=\alpha+\mathrm{p} 1 . \mathrm{X} 1+\mathrm{p} 3 . \mathrm{X} 3+\mathrm{e} 2$ & \\
\cline { 2 - 2 } & $\mathrm{KL}=19,655+0,344 \mathrm{SDM}+\mathrm{e} 2$ & \multirow{2}{*}{0,561} \\
\hline \multirow{2}{*}{3} & $\mathrm{X} 3=\alpha+\mathrm{p} 5 . \mathrm{X} 2+\mathrm{e} 3$ & \multirow{2}{*}{0,269} \\
\cline { 2 - 2 } & $\mathrm{SPIP}=9,785+1,176 \mathrm{TI}+\mathrm{e} 3$ & \\
\hline \multirow{2}{*}{4} & $\mathrm{Y}=\alpha+\mathrm{p} 4 . \mathrm{X} 2+\mathrm{p} 6 . \mathrm{X} 3+\mathrm{e} 4$ & \\
\cline { 2 - 3 } & $\mathrm{KL}=2,565+\mathrm{e} 4$ & \multicolumn{1}{|c}{} \\
\hline
\end{tabular}

Sumber: Data primer, diolah (2014)

Tabel 5 menunjukkan nilai adjusted $R^{2}$ pada persamaan 1 sebesar 0,550 atau $55 \%$. Hal ini menunjukkan bahwa variabel sistem pengendalian intern pemerintah yang dapat dijelaskan oleh variabel kapasitas sumberdaya manusia sebesar $55 \%$. Nilai adjusted $R^{2}$ pada persamaan 2 sebesar 0,283 atau 28,3\%. Hal ini menunjukkan 
bahwa variabel kualitas laporan keuangan yang dapat dijelaskan oleh variabel kapasitas sumberdaya manusia dan sistem pengendalian intern pemerintah sebesar $28,3 \%$.

Tabel 5 menunjukkan nilai adjusted $R^{2}$ pada persamaan 3 sebesar 0,561 atau $56,1 \%$. Hal ini menunjukkan bahwa variabel sistem pengendalian intern pemerintah yang dapat dijelaskan oleh variabel pemanfaatan teknologi informasi sebesar $56,1 \%$. Nilai adjusted $R^{2}$ pada persamaan 4 sebesar 0,269 atau $26,9 \%$. Hal ini menunjukkan bahwa variabel kualitas laporan keuangan yang dapat dijelaskan oleh variabel pemanfaatan teknologi informasi dan sistem pengendalian intern pemerintah adalah sebesar $26,9 \%$.

\section{b. Uji F}

\section{Tabel 6}

Hasil Uji F

\begin{tabular}{|c|l|c|c|}
\hline No & \multicolumn{1}{|c|}{ Persamaan Regresi } & F & Signifikansi \\
\hline \multirow{2}{*}{1} & $\mathrm{X} 3=\alpha+\mathrm{p} 2 . \mathrm{X} 1+\mathrm{e} 1$ & \multirow{2}{*}{82,891} & 0,000 \\
\cline { 2 - 2 } & $\mathrm{SPIP}=9,295+1,094 \mathrm{SDM}+\mathrm{e} 1$ & & \\
\hline \multirow{2}{*}{2} & $\mathrm{Y}=\alpha+\mathrm{p} 1 . \mathrm{X} 1+\mathrm{p} 3 . \mathrm{X} 3+\mathrm{e} 2$ & \multirow{2}{*}{14,246} & 0,000 \\
\cline { 2 - 2 } & $\mathrm{KL}=19,655+0,344 \mathrm{SDM}+\mathrm{e} 2$ & & \\
\hline \multirow{2}{*}{3} & $\mathrm{X} 3=\alpha+\mathrm{p} 5 . \mathrm{X} 2+\mathrm{e} 3$ & \multirow{2}{*}{86,456} & 0,000 \\
\cline { 2 - 2 } & $\mathrm{SPIP}=9,785+1,176 \mathrm{TI}+\mathrm{e} 3$ & \multirow{2}{*}{13,314} & 0,000 \\
\hline \multirow{2}{*}{4} & $\mathrm{Y}=\alpha+\mathrm{p} 4 . \mathrm{X} 2+\mathrm{p} 6 . \mathrm{X} 3+\mathrm{e} 4$ & & \\
\cline { 2 - 3 } & $\mathrm{KL}=2,565+\mathrm{e} 4$ & & \\
\hline
\end{tabular}

Sumber: Data primer, diolah (2014)

Hasil uji $\mathrm{F}$ menunjukkan bahwa persamaan regresi 1 mempunyai nilai $\mathrm{F}$ hitung sebesar 82,891 dengan tingkat signifikansi 0,000 yang jauh lebih kecil dari 0,05. Hal itu menunjukkan bahwa kapasitas sumberdaya manusia berpengaruh terhadap sistem pengendalian intern pemerintah. Regresi 2 mempunyai nilai $\mathrm{F}$ hitung sebesar 14,246 dengan tingkat signifikansi 0,000 yang jauh lebih kecil dari 0,05. Hal itu menunjukkan bahwa model regresi dapat digunakan untuk memprediksi kualitas laporan keuangan atau dapat dikatakan bahwa kapasitas 
sumberdaya manusia dan sistem pengendalian intern pemerintah secara bersamasama berpengaruh terhadap kualitas laporan keuangan.

Hasil uji $\mathrm{F}$ menunjukkan bahwa persamaan regresi 3 mempunyai nilai $\mathrm{F}$ hitung sebesar 86,456 tingkat signifikansi 0,000 yang jauh lebih kecil dari 0,05. Hal itu menunjukkan bahwa adanya pengaruh variabel independen dalam hal ini pemanfaatan teknologi informasi terhadap variabel sistem pengendalian intern pemerintah sebagai variabel dependen. Regresi 4 mempunyai nilai F hitung sebesar 13,314 dengan tingkat signifikansi 0,000 yang jauh lebih kecil dari 0,05. Hal itu menunjukkan bahwa model regresi dapat digunakan untuk memprediksi kualitas laporan keuangan atau dapat dikatakan bahwa pemanfaatan teknologi informasi dan sistem pengendalian intern pemerintah secara bersama-sama berpengaruh terhadap kualitas laporan keuangan.

\section{c. Uji t}

Tabel 7

Hasil Uji t

\begin{tabular}{|c|l|}
\hline No & \multicolumn{1}{|c|}{ Persamaan Regresi } \\
\hline \multirow{3}{*}{1} & $\mathrm{X} 3=\alpha+\mathrm{p} 2 . \mathrm{X} 1+\mathrm{e} 1$ \\
\cline { 2 - 2 } & $\mathrm{SPIP}=9,295+1,094 \mathrm{SDM}+\mathrm{e} 1$ \\
\cline { 2 - 2 } & $p$ value $(0,000)$ \\
\hline \multirow{2}{*}{2} & $\mathrm{Y}=\alpha+\mathrm{p} 1 . \mathrm{X} 1+\mathrm{p} 3 . \mathrm{X} 3+\mathrm{e} 2$ \\
\cline { 2 - 2 } & $\mathrm{KL}=19,655+0,344 \mathrm{SDM}+0,182 \mathrm{SPIP}+\mathrm{e} 2$ \\
\cline { 2 - 2 } & $p$ value $\quad(0,036)$ \\
\hline \multirow{3}{*}{3} & $\mathrm{X} 3=\alpha+\mathrm{p} 5 . \mathrm{X} 2+\mathrm{e} 3$ \\
\cline { 2 - 2 } & $\mathrm{SPIP}=9,785+1,176 \mathrm{TI}+\mathrm{e} 3$ \\
\cline { 2 - 2 } & $p$ value $\quad(0,000)$ \\
\hline \multirow{3}{*}{4} & $\mathrm{Y}=\alpha+\mathrm{p} 4 . \mathrm{X} 2+\mathrm{p} 6 . \mathrm{X} 3+\mathrm{e} 4$ \\
\cline { 2 - 2 } & $\mathrm{KL}=2,565+0,313 \mathrm{TI}+0.206 \mathrm{SPIP}+\mathrm{e} 4$ \\
\cline { 2 - 2 } & $p$ value $\quad(0,079)$ \\
\hline
\end{tabular}

Sumber: Data primer, diolah (2014)

Hipotesis pertama digunakan persamaan 2, bahwa kapasitas sumberdaya manusia berpengaruh terhadap kualitas laporan keuangan pemerintah daerah dengan nilai signifikansi $0,036<0,05$. Sumberdaya manusia yang ada di 
lingkungan pemerintah daerah Kota Cirebon dituntut untuk memiliki tingkat akuntansi yang memadai atau paling tidak memiliki kemauan untuk terus belajar dan mengasah kemampuan di bidang akuntansi. Ketika pegawai yang ada di lingkungan pemerintah daerah Kota Cirebon memiliki kapasitas yang dibutuhkan untuk melaksanakan tugas yang menjadi pekerjaan atau tanggungjawabnya, maka pegawai tersebut dapat menyelesaikan dengan baik dan cepat. Oleh karena itu, kapasitas sumberdaya manusia sangat berperan dalam menghasilkan laporan keuangan yang berkualitas.

Hipotesis kedua digunakan persamaan 4, bahwa pemanfaatan teknologi informasi tidak berpengaruh terhadap kualitas laporan keuangan pemerintah daerah dengan nilai signifikansi 0,079 sehingga hipotesis kedua dalam penelitian ini ditolak karena nilai signifikansi lebih dari 0,05. Hal ini dapat disebabkan oleh teknologi informasi yang belum dimanfaatkan dan diimplementasikan secara optimal sehingga tidak dapat mendukung penyajian laporan keuangan yang handal.

Hipotesis ketiga digunakan persamaan 1, bahwa kapasitas sumberdaya manusia berpengaruh terhadap sistem pengendalian intern pemerintah daerah dengan nilai signifikansi 0,000 kurang dari 0,05. Kegagalan sumberdaya manusia pemerintah daerah dalam memahami dan menerapkan logika akuntansi akan berdampak pada kekeliruan laporan keuangan yang dibuat dan ketidaksesuaian laporan dengan standar yang ditetapkan pemerintah. Pengendalian dalam aktivitas pemerintah akan mendorong pemakaian sumberdaya, mencakup personil, secara efisien dan efektif untuk mengoptimalkan sasaran-sasaran yang hendak dicapai. Aspek yang paling penting dari pengendalian internal adalah personil.

Hipotesis keempat digunakan persamaan 3, bahwa pemanfaatan teknologi informasi berpengaruh terhadap sistem pengendalian intern pemerintah daerah dengan nilai signifikansi 0,000 . Hipotesis keempat dalam penelitian ini diterima karena nilai signifikansi kurang dari 0,05. Pemanfaatan teknologi informasi berkaitan dengan unsur informasi dan komunikasi. Pimpinan instansi pemerintah wajib mengidentifikasi, mencatat, dan mengkomunikasikan informasi dalam bentuk dan waktu yang tepat. Komunikasi atas informasi wajib diselenggarakan secara efektif. Pimpinan instansi pemerintah harus menyediakan dan memanfaatkan 
berbagai bentuk dan sarana komunikasi, serta mengelola, mengembangkan, dan memperbarui sistem informasi secara terus menerus.

Hipotesis kelima digunakan persamaan 2, bahwa sistem pengendalian intern pemerintah tidak berpengaruh terhadap kualitas laporan keuangan pemerintah daerah dengan nilai signifikansi 0,102 . Hipotesis kelima dalam penelitian ini ditolak karena nilai signifikansi lebih dari 0,05. Hal ini bisa disebabkan karena rendahnya pengendalian yang dilakukan oleh pimpinan, pemisahan tugas yang kurang jelas, dan setiap transaksi bisa dilakukan tanpa otorisasi pihak yang berwenang.

Syarat utama pengujian variabel intervening adalah variabel sistem pengendalian intern pemerintah mempunyai pengaruh terhadap kualitas laporan keuangan. Hasil pengujian hipotesis 5 menunjukkan bahwa sistem pengendalian intern pemerintah tidak berpengaruh terhadap kualitas laporan keuangan. Dengan demikian, penelitian ini menolak hipotesis 6 yang menyatakan bahwa sistem pengendalian intern pemerintah dapat memediasi pengaruh kapasitas sumberdaya manusia terhadap kualitas laporan keuangan pemerintah daerah Kota Cirebon. Aspek yang paling penting dari pengendalian internal adalah personil. Fakta di lapangan menunjukkan bahwa karyawan yang ada di lingkungan pemerintah daerah Kota Cirebon memiliki kompetensi yang baik, namun lemah dalam pengendalian internal. Hal tersebut dibuktikan dengan hasil kuesioner yang mayoritas responden tidak setuju dengan pernyataan transaksi tidak dapat dilakukan tanpa adanya otorisasi dari pihak berwenang.

Penelitian ini juga menolak hipotesis 7 yang menyatakan bahwa sistem pengendalian intern pemerintah dapat memediasi pengaruh pemanfaatan teknologi informasi terhadap kualitas laporan keuangan pemerintah daerah Kota Cirebon. Hasil penelitian ini sesuai dengan fakta yang ada di lapangan. Setiap SKPD yang ada di lingkungan pemerintah daerah Kota Cirebon telah memiliki teknologi informasi baik berupa hardware (komputer dan laptop) maupun software Sistem Akuntansi Keuangan Daerah (SAKD). Permasalahan yang timbul yaitu karyawan. 


\section{SIMPULAN, KETERBATASAN, DAN SARAN}

Simpulan yang dapat diambil dari hasil analisis data adalah kapasitas sumberdaya manusia berpengaruh terhadap kualitas laporan keuangan pemerintah daerah Kota Cirebon. Pemanfaatan teknologi informasi dan sistem pengendalian intern pemerintah tidak berpengaruh terhadap kualitas laporan keuangan pemerintah daerah Kota Cirebon. Kapasitas sumberdaya manusia dan pemanfaatan teknologi informasi berpengaruh terhadap sistem pengendalian intern pemerintah daerah Kota Cirebon. Sementara itu, sistem pengendalian intern pemerintah tidak berpengaruh terhadap kualitas laporan keuangan pemerintah daerah Kota Cirebon. Oleh karena itu, sistem pengendalian intern pemerintah tidak mampu memediasi pengaruh kapasitas sumberdaya manusia dan pemanfaatan teknologi informasi terhadap kualitas laporan keuangan pemerintah daerah Kota Cirebon.

Penelitian ini masih banyak kekurangan yang perlu disempurnakan. Hal ini dikarenakan masih terdapat beberapa keterbatasan sebagai berikut.

1. Sikap kepedulian dan keseriusan yang kurang dalam menjawab kuesioner menjadi kendala dalam penelitian ini.

2. Masalah subjektivitas dari responden dapat mengakibatkan hasil penelitian ini rentan terhadap biasnya jawaban responden. Hal ini disadari oleh peneliti merupakan keterbatasan dalam penelitian yang menggunakan data primer.

Berdasarkan hasil penelitian yang telah dilakukan, saran yang dapat diajukan untuk penelitian selanjutnya adalah:

1. Melengkapi metoda survei dengan wawancara untuk meningkatkan sikap kepedulian dan keseriusan responden dalam menjawab kuesioner dan mengurangi subjektivitas dari responden yang bisa mengakibatkan hasil penelitian ini rentang terhadap biasnya jawaban responden.

2. Penelitian ini masih terbatas pada kapasitas sumber daya manusia, pemanfaatan teknologi informasi dan sistem pengendalian intern pemerintah terhadap kualitas laporan keuangan pemerintah daerah. Penelitian selanjutnya dapat dilakukan perubahan variabel penelitian untuk menemukan variabel-variabel lain yang berpengaruh. 


\section{DAFTAR PUSTAKA}

Akuntabilitas Pelaporan Keuangan, [Online] Didapatkan: <http:// www.bpkp.go.id/konten/419/Akuntabilitas-Pelaporan-Keuangan.bpkp [16> November 2013].

Arfianti, Dita. 2011. Analisis Faktor-faktor yang Mempengaruhi Nilai Informasi Pelaporan Keuangan Pemerintah Daerah pada SKPD di Kabupaten Batang [Online]. Didapatkan: <http://eprints.undip.ac.id/29808/1/Skripsi018.pdf [15> September 2013].

Boynton, William, Raymond Johnson, dan Walter Kell. 2003. Modern Auditing. Ed. 7. Jakarta: Erlangga.

Delanno, F, Galuh. 2013. "Pengaruh Kapasitas Sumberdaya Manusia, Pemanfaatan Teknologi Informasi, dan Pengawasan Keuangan terhadap Nilai Informasi Pelaporan Keuangan Pemerintah Daerah”. Jurnal Wahana Riset Akuntansi Universitas Negeri Padang (April), hal. 21-45.

Ghozali, Imam. 2011. Aplikasi Analisis Multivariate dengan Program IBM SPSS 19. Semarang: Badan Penerbit Universitas Diponegoro.

Indriantoro, Nur dan Bambang Supomo. 2012. Metodologi Penelitian Bisnis. Yogyakarta: BPFE UGM.

Indriasari, Desi. 2008. Pengaruh Kapasitas Sumberdaya Manusia, Pemanfaatan Teknologi Informasi, dan Pengendalian Intern Akuntansi terhadap Nilai Informasi Pelaporan Keuangan Pemerintah Daerah. Tesis. Yogyakarta: Universitas Gajah Mada.

Latif, Achmad Badarudin. 2007. Hubungan antara Keadilan Prosedural dan Kinerja Manajerial dengan Partisipasi Anggaran sebagai Variabel Intervening [Online]. Didapatkan: http://eprints.undip.ac.id [14 Oktober 2013].

Mardiasmo. 2009. Akuntansi Sektor Publik. Ed. II. Yogyakarta: Andi Offset.

Musa, Ali Masykur. 2013. BPK RI Lakukan Quality Assurance Keuangan Negara [Online]. Didapatkan: <http://www.bpk.go.id [16> November 2013].

Peraturan Pemerintah Nomor 71 Tahun 2010 tentang Standar Akuntansi Pemerintahan. 
Peraturan Pemerintah Nomor 65 Tahun 2010 tentang Sistem Informasi Daerah.

Peraturan Pemerintah Nomor 60 Tahun 2008 tentang Sistem Pengendalian Intern Pemerintah.

Peraturan Presiden Republik Indonesia Nomor 59 Tahun 2012 tentang Kerangka Nasional Pengembangan Kapasitas Pemerintahan Daerah.

Puspitasari, Elen. 2013. "Peran Karakteristik Sistem Akuntansi Manajemen sebagai Variabel yang Memediasi Pengaruh Teknologi Informasi dan saling Ketergantungan terhadap Kinerja Manajerial”. Jurnal Dinamika Akuntansi, Keuangan, dan Perbankan Vol. 2 Universitas Diponegoro Semarang (Mei), hal.1-13.

Suwardjono. 2013. Teori Akuntansi: Perekayasaan Pelaporan Keuangan. Ed. 3. Yogyakarta: BPFE UGM.

Undang-Undang Nomor 17 Tahun 2003 tentang Keuangan Negara.

Undang-Undang Nomor 32 Tahun 2004 tentang Pemerintahan Daerah.

Wilkinson, Josep W, Michael J. Cerullo, Vasant Raval, Bernard Wong On Wing. 2000. Accounting Information Systems: Essential Concepts and Applications. Ed. 4. United States: John Willey \& Sons, Inc.

Wirawan. 2009. Evaluasi Kinerja Sumberdaya Manusia: Teori, Aplikasi, dan Penelitian. Jakarta: Salemba Empat.

Yosefrinaldi. 2013. Pengaruh Kapasitas Sumber Daya Manusia dan Pemanfaatan Teknologi Informasi terhadap Kualitas Laporan Keuangan Pemerintah Daerah dengan Variabel Intervening Sistem Pengendalian Intern Pemerintah [Online]. Didapatkan: <http://ejournal.unp.ac.id/6> [5 September 2013].

Zuliarti. 2012. Pengaruh Kapasitas Sumber Daya Manusia, Pemanfaatan Teknologi Informasi, dan Pengendalian Intern Akuntansi terhadap Nilai Informasi Pelaporan Keuangan Pemerintah Daerah: Studi pada Pemerintah Kabupaten Kudus [Online]. Didapatkan:

<http://eprints.umk.ac.id> [5 September 2013]. 